\title{
クリッピング術の術前スコアリングよりみた
} 未破裂脳動脈瘤の治療選択

一高スコア症例の血管内手術または経過観察への振り分け一

$$
\begin{aligned}
& \text { 松本 勝美, 山本 聡, 鶴園浩一郎 }{ }^{1} \\
& \text { 高見 昌明 }{ }^{1} \text {, 芳村 憲泰, 早川 徹 }{ }^{1} \\
& \text { 太田 富雄 }{ }^{1} \text {, 藤中 俊之 }{ }^{2} \text {, 吉峰 } \text { 俊樹 }^{2}
\end{aligned}
$$

\section{Therapeutic Choice of the Unruptured Cerebral Aneurysms Following Prediction of the Treatment Outcome Using a Preoperative Scoring}

Katsumi Matsumoto, M.D., ${ }^{1}$ Satoshi Yamamoto, M.D., ${ }^{1}$ Kouichirou Turuzono, M.D., ${ }^{1}$ Masaaki Takami, M.D., ${ }^{1}$ Kazuhiro Yoshimura, M.D., ${ }^{1}$ Toru Hayakawa, M.D., ${ }^{1}$

Tomio Oota, M.D., ${ }^{1}$ Toshiyuki Fujinaka, M.D., ${ }^{2}$ and Toshiki Yoshimine, M.D. ${ }^{2}$

${ }^{1}$ Department of Neurosurgery, Iseikai Hospital, Osaka, and ${ }^{2}$ Department of Neurosurgery, Osaka University School of Medicine, Suita, Japan

Summary: Complication of the surgical treatment for unruptured cerebral aneurysms is not ignorable especially for high-risk patients whose preoperative score is more than 2 . The preoperative score consisted of aneurysm size (0: below $14 \mathrm{~mm}, 1$ : 15-24 mm, 2: over $25 \mathrm{~mm}$ ), location (0: other location than posterior fossa and paraclinoid, 1: paraclinoid, 2: posterior fossa), multiplicity (0: treatable with single approach, 1: different approach necessary), and systemic diseases ( 0 : no disease other than cerebral aneurysm, 1: one disease, 2: more than 2 diseases). Since 1997, we have conducted preoperative scoring and managed the unruptured cerebral aneurysms with scores of over 2 by observation, intravascular surgery or clipping surgery. Surgical results were evaluated using a modified Rankin scale (mRS). Before scoring, surgical complications exceeding mRS III occurred in $7.5 \%$ of cases, whereas this figure declined to $2.5 \%$ in the surgical results since 1997 . When results of clipping surgery and intravascular surgery were compared, the former showed $3.8 \%$ and the latter showed $0 \%$ of complications exceeding mRS III.

The results indicate that clipping surgery combined with intravascular surgery improves surgical outcome for unruptured cerebral aneurysms with high risk.
Key words:

- clipping

- unruptured aneurysms

- surgical risk

- intravascular surgery

Surg Cereb Stroke (Jpn) 34: 405-408, 2006

\footnotetext{
${ }^{1}$ 医誠会病院 脳神経外科, ${ }^{2}$ 大阪大学医学部 脳神経外科(受稿日 2005.9.5) (脱稿日 2005.10.19)〔連絡先： 于533-0022 大阪市東淀川 区菅原 6丁目 2-25 医誠会病院 脳神経外科 松本勝美] [Address correspondence: Katsumi MATsumoto, M.D., Department of Neurosurgery, Iseikai Hospital, 6-25 Sugawara, Higashi-Yodogawa-ku, Osaka City, Osaka 533-0022, Japan]
} 


\section{はじめに}

未破裂脳動脈瘤の治療成績は mortality で $0-3.8 \%{ }^{1 / 6) 8}$ ) 13) 20), morbidity で 2-15.8\% ${ }^{15) 6) 8) 13) 20)}$ と報告され, 施設で の差異がかなりがあるが概して低いものではない，手術合 併症をきたしやすい要因として動脈瘤のサイズ7)8110)16)17), 部位 $\left.{ }^{8)}{ }^{10)} 16\right)$ や脳梗塞などの合併 ${ }^{10)}{ }^{18)}$ などがあげられる. われわれは，術前にスコアリングを施行しスコアが 2 以上 では手術合併症が多いことを報告した ${ }^{10)}$ 。一方で 1997 年 以降は本邦でも GDCが認可され，血管内手術が未破裂脳 動脈瘤の治療に大きな役割を果たすようになってきた ${ }^{15)}$. 以上を背景に 1997 年以降はスコア 0-1をクリッピング優 先で治療を行い，手術合併症をきたしやすいスコア 2 以上 の症例に対しては個別に血管内治療とクリッピングの両者 いずれかでもっとも安全に対処しうる選択をすることとし た。その結果と問題点について報告する.

\section{対象および方法}

過去 13 年間で，くも膜下出血をきたした多発動脈瘤の 破裂脳動脈瘤との同時手術を除く未破裂脳動脈瘤 272 例中 157 例に治療を行い，これらについて治療成績を中心に検 討した１997年以前には血管内治療はなく，クリッピン グ手術を 84 例に施行，1997 年以降ではクリッピング 56 例 および血管内治療 17 例を施行した。術前スコアリングは, サイズ (0: $14 \mathrm{~mm}$ 以下，1: 15-24 mm, 2: $25 \mathrm{~mm}$ 以上), 部 位 (1: carotid cave, 2: 後頭蓋窩, 0: その他), 全身合併症 (0: なし，1：1つ，2:2つ以上), 多発性 (0: 1箇所の開頭, 1: 2 筒所以上) で行った。治療成績は 6 力月後の modified Rankin Scale (mRS)で判定した ${ }^{10)}$. 1997 年以前は血管内 治療は選択せず，1997年以降はスコア 0-1をクリッピン グ優先，スコア 2 以上をクリッピングと血管内治療の選択 をケースバイケースで行った。治療選択は複数の術者が関 与し，クリッピング手術に関してはすべて経験数 50 例以 上の術者が判断し，血管内治療に関してはすべて経験数 20 例以上の術者が判断した。

\section{結果}

症例の治療のふりわけを Table 1 に示す. スコア 2 以上 の高リスク群での治療については，スコアリング導入前後 で治療にふみきった数は約半数と変わらないが，導入後で は血管内治療の割合が増加したため，クリッピングの率は 低下した。 スコア 0-1の例については導入後は手術リスク が低いにもかかわらず経過観察の症例が増加したが，これ は主にサイズ $3 \mathrm{~mm}$ 以下の症例で経過観察になる症例が増 加したのが原因と考えられる。 スコアリング導入前では平 均年齢 57 歳, 平均サイズ $7.3 \mathrm{~mm}$, 平均スコア 1.4 である のに対し，導入後は平均サイズは $5.9 \mathrm{~mm}$ とやや低下した が平均年齢 61 歳, 平均スコア 1.7 と高くなった。

スコアリング導入前の治療成績を Fig. 1 に示す. ISUIA などで用いられている mRS III 以上の症例は，1）スコア 2 以上では $7.5 \%$ と高く, mRS I-VIでみると $10 \%$ に達した. スコアリング導入後では Fig. 2 に示すようにスコア 2 以上 の群では mRS III 以上は $2.5 \%, \mathrm{mRS} \mathrm{I-VIでみると} 7.5 \%$ と 減少した。このうち導入後でクリッピング手術と血管内手 術を比較すると（Fig. 3)，前者は mRS III 以上が $3.8 \%$, mRS I-VIが $11.3 \%$ と高かったのに比して，血管内手術で は $\mathrm{mRS}$ III 以上は $0 \%, \mathrm{mRS}$ I-VIでも $7.1 \%$ と低く, スコ



Fig. 1 Surgical outcome before induction of scoring (before 1997).

Table 1 Treament for unruptured cerebral aneurysms (number of cases (\%))

\begin{tabular}{lcll}
\hline & Observation & Clipping & \multicolumn{1}{c}{ Endovascular } \\
\hline \multicolumn{3}{c}{ Before induction of Scoring (before 1997) } & \\
Score 0-1 & $16(27 \%)$ & $44(73 \%)$ & 0 \\
Score over 2 & $35(47 \%)$ & $40(53 \%)$ & 0 \\
& & \\
Following induction of Scoring (after 1997) & \\
Score 0-1 & $35(52 \%)$ & $29(43 \%)$ & $3(5 \%)$ \\
Score over 2 & $46(53 \%)$ & $27(31 \%)$ & $14(16 \%)$ \\
\hline
\end{tabular}


ア導入後に手術成績が改善したのは血管内治療が関与した 効果が大きいと考えられた。

しかしながら Fig. 4 に示すように, 多発脳動脈瘤の治療 に際し，両者を併用することでかえって合併症を招いた例 もある. 症例は 60 歳女性で, 左内頸動脈瘤, 左中大脳動 脈瘤と脳底動脈瘤を認め, 前者 2 個をクリッピングし, そ の後後者を塞栓したところ脳塞栓症を併発し, 後頭葉脳梗 塞をきたし同名半盲が後遺症として残った。この例は retrospectiveにみて脳底動脈瘤に血管内治療を選択するより はクリッピングを同時に施行したほうが，治療ステップが 最小限ででき結果的には合併症を減らせた可能性もある.

\section{考察}

スコアリング 2 以上の症例においては, 多発脳動脈瘤や, サイズの大きい動脈瘤, 後頭蓋周動脈瘤など自然歴でみて も破裂のリスクの高い症例が多く含まれ，治療を避けるわ けにはいかないケースも多い。

破裂脳動脈瘤に関しては治療のふりわけや統計デザイン にさまざまな問題はあるものの，ISATにて主に軽症くも
膜下出血に関しての血管内治療の有効性が実証された ${ }^{14)}$. 一方，未破裂脳動脈瘤の治療成績に関してはいまだ国際的 研究はなされていない. Lanternaの 1990-2002年までの 文献をまとめた review では，未破裂脳動脈瘤の血管内手 術成績は mortality $0.6 \%$, morbidity $7 \%$ で，かつ術後の年 間破裂率は $0.9 \%$ あり，けっして満足のいく結果にはなっ ていないが9)，1998年の ISUIAの morbidityと mortaliy

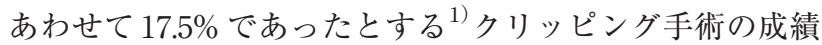
よりは良好な結果となった。さらに 2003 年の ISUIAの追 加報告ではクリッピング手術の合併症が mortality, morbidity あわせて $12.6 \%$ であったのに対して，血管内治療で は 9.8\%とやや下回っている ${ }^{19)}$ 。これらの結果は治療群の 背景が違い比較は困難ではあるが，血管内治療は症例を選 択すれば手術合併症を減らせる可能性を示唆するものであ る.

血管内治療と開頭クリッピング手術を組み合わせた症例 を1例のみ提示したが，治療ステップが増加するとそれだ け合併症が増加することを銘記すべきと考えられた。

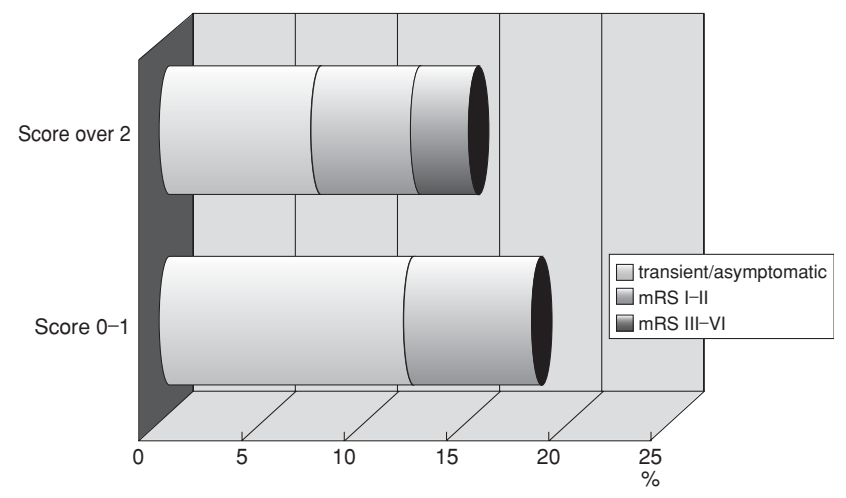

Fig. 2 Surgical outcome following induction of scoring lafter 1997).



Fig. 3 Comparison of the surgical outcome between clipping surgery and endovascular treatment since 1997.
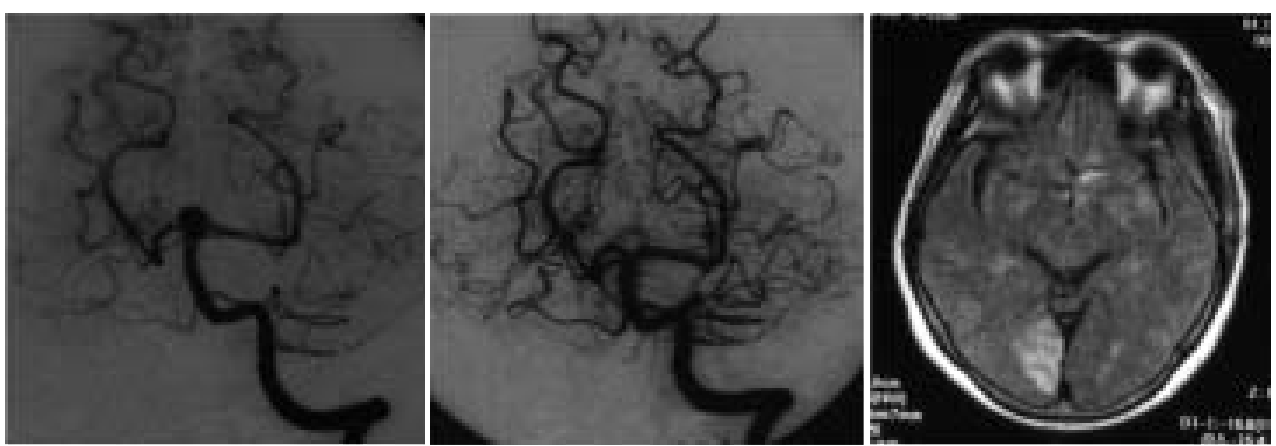

Fig. 4 A case of 60 year old women having left middle cerebral artery aneurysm, left interna carotid artery aneurysm and basilar aneurysm (leff). Basilar aneurysm was treated with GDC. There was no major artery occlusion by cerebral angiography (middle). However, she had left homonymous hemianopsia and MRI (Flair) revealed a cerebral infarction in the right occipital lobe. 


\section{まと め}

スコア 2 以上の治療合併症の多い未破裂脳動脈瘤に対し 血管内治療を適用することで治療成績は向上した，両者を 併用した治療に関しては，より慎重に適応を考えるべきと 思われた。

\section{文献}

1) Authors: International Study of Unruptured Intracranial Aneurysms Investigators: Unruptured intracranial aneurysms: Risk of rupture and risks of surgical intervention. N Engl J Med 339: 1725-1733, 1998

2) Baker FG, Amin-Hanjani S, Butler WE, et al: Age-dependent differences in intracranial aneurysms in the United States, 1996-2000. Neurosurgery 54: 18-28, 2004

3) Brennan JW, Schwartz ML: Unruptured intracranial aneurysms: Appraisal of the literature and suggested recommendations for surgery, using evidence-based medicine criteria. Neurosurgery 47: 1359-1372, 2000

4) Chung RY, Carter BS, Norbash A, et al: Management outcome for ruptured and unruptured aneurysms in the elderly. Neurosurgery 47: 827-833, 2000

5) Chyatte D, Porterfield R: Functional outcome after repair of unruptured intracranial aneurysms. $J$ Neurosurg 94: 417-421, 2001

6) Deruty R, Pelissou-Guyotat I, Mottolese C, et al: Management of unruptured cerebral aneurysms. Neurol Res 18: 39-44, 1996

7）池田清延, 山下純宏：未破裂腮動脈瘤の外科的治療戦略. 脳卒中の外科 21: 231-237, 1993

8) Khanna RK, Malik GM, Qureshi N: Predicting outcome following surgical treatment of unruptured intracranial aneurysms: a proposed grading system. $J$ Neurosurg 84: 49-54, 1996

9) Lanterna LA, Tredici G, Dimitrov BD, et al: Treatment of unruptured cerebral aneurysms by embolization with Guglielmi detachable coils: Case-fatality, morbidity, and effectiveness in preventing bleeding-A systematic review of the literature. Neurosurgery 55: 767-778, 2004

10）松本勝美，赤木功人，安部倉 信，ほか：未破裂脳動脈瘤 の術前スコアリングと手術合併症. 脳神経外科 25: 785-790, 1997

11）松本勝美，赤木功人，安部倉 信，ほか：脳虚血病変精査 中に発見された未破裂脳動脈瘤の治療選択と合併症. 脳神 経外科 28: 699-703, 2000

12) Matsumoto K, Akagi K, Abekura M, et al: Investigation of the surgically treated and untreated unruptured cerebral aneurysms of the anterior circulation. Surg Neurol 60: 516-523, 2003

13) Mizoi K, Yoshimoto $T$, Nagamine $Y$, et al: How to treat incidental cerebral aneurysms: A review of 139 consecutive cases. Surg Neurol 44: 114-121, 1995

14) Molyneux A, Kerr R, Stratton I, et al: International Subarachnoid Aneurysms Trial (ISAT) of neurosurgical clipping versus endovascular coiling in 2143 patients with ruptured intracranial aneurysms: a randomized trial. Lancet 360: 1267-1274, 2002

15）村山雄一，佐口隆之，石橋敏寛，ほか：脳動脈瘤に対する 脳血管内治療の現状と将来. 脳卒中の外科 33: 81-84, 2005

16) Raaymakers TWM, Rinkel GJE, Limburg M, et al: Mortality and morbidity of surgery for unruptured intracranial aneurysms. A meta-analysis. Stroke 29: 15311538, 1998

17) Solomon RA, Fink ME, Pile-Spellman J: Surgical management of unruptured intracranial aneurysms. $J$ Neurosurg 80: 440-446, 1994

18）鈴木倫保, 加藤祥一, 秋村龍夫, ほか：脳虚血発症未破裂 脳動脈瘤. 脳卒中の外科 32: 126-132, 2004

19) Wiebers DO, Whisnant JP, Huston J 3rd, et al: Unruptured intracranial aneurysms: natural history, clinical outcome, and risks of surgical and endovascular treatment. Lancet 362: 103-110, 2003

20) Wirth FP, Laws ER Jr, Piepgras DG, et al: Surgical treatment of incidental intracranial aneurysms. Neurosurgery 12: 507-511, 1983 